\title{
Replacing corn with glycerol in diets for transition dairy cows
}

\author{
E. R. Carvalho, ${ }^{*}$ N. S. Schmelz-Roberts, $†$ H. M. White, $†$ P. H. Doane, $\ddagger$ and S. S. Donkin ${ }^{1}$ \\ *University of Goiás, Goiânia, GO, Brazil, 74001-970 \\ †Department of Animal Sciences, Purdue University, West Lafayette, IN 47907 \\ ‡Archer Daniels Midland Company, Decatur, IL 62521
}

\begin{abstract}
Expansion of the biofuels industry has increased the availability of glycerol as an alternative feed for dairy cows. The objective of this study was to determine the effects of glycerol on feed intake, milk production, rumen volatile fatty acids, and metabolic parameters in transition dairy cows. Multiparous Holstein cows were fed diets containing either high-moisture corn $(\mathrm{n}=11)$ or glycerol $(\mathrm{n}=12)$ from -28 to $+56 \mathrm{~d}$ relative to calving. Glycerol was included at 11.5 and $10.8 \%$ of the ration dry matter for the pre- and postpartum diets, respectively. Prepartum feed intake was not changed by glycerol feeding (14.9 vs. $14.6 \mathrm{~kg} / \mathrm{d}$, control vs. glycerol) nor did postpartum feed intake differ (19.8 vs. $20.7 \mathrm{~kg} / \mathrm{d}$, control vs. glycerol). Overall milk yield did not differ ( 35.8 vs. $37 \mathrm{~kg} / \mathrm{d}$, control vs. glycerol) and milk composition, milk urea nitrogen, somatic cells, and energy balance were not different with glycerol feeding. Blood glucose content was decreased in cows fed glycerol during the prepartum period (59.1 vs. $53.4 \mathrm{mg} / \mathrm{dL}$ ), and $\beta$-hydroxybutyrate concentration was increased ( 0.58 vs. $0.82 \mathrm{mmol} / \mathrm{L}$, control vs. glycerol). Concentrations of blood nonesterified fatty acids did not differ between the treatment groups, and no response to glycerol for blood metabolites during the postpartum period was observed. Total rumen volatile fatty acid concentrations $(\mathrm{mmol} / \mathrm{L})$ did not differ between treatments, but proportions of rumen propionate and butyrate were greater for cows fed glycerol (22.7 vs. $28.6 \%$ of propionate, control vs. glycerol; and 11.5 vs. $15.3 \%$ of butyrate, control vs. glycerol) at the expense of acetate ( 61.4 vs. $51.5 \%$, control vs. glycerol). These data indicate that glycerol is a suitable replacement for corn grain in diets for transition dairy cows.
\end{abstract}

Key words: glycerol, energy, biofuel, transition cow

Received June 30, 2010.

Accepted October 15, 2010.

${ }^{1}$ Corresponding author: sdonkin@purdue.edu.

\section{INTRODUCTION}

Expansion of the biofuels industry around the world has provided opportunities for alternative energy sources for livestock. In many cases the amount of glycerol coproduct has exceeded the capacities of the pharmaceutical and chemical industries for refinement and further processing (Thompson and He, 2006). Consequently, opportunities may exist to use glycerol as an energy source in diets for dairy cattle; however, little is known about the feeding value of glycerol or tolerable levels of glycerol that can be fed across the lactation cycle.

According to the FDA (2006), glycerol is recognized as a safe ingredient for use in animal feeds. The value of glycerol as a treatment for ketosis was realized over 50 years ago (Johnson, 1954) and evaluation of glycerol as a ketosis treatment was explored 40 years ago (Fisher et al., 1971) and then again more recently (Goff and Horst, 2001). Glycerol has been fed at levels ranging from 0.25 (Chung et al., 2007) to $0.86 \mathrm{~kg} / \mathrm{d}$ (DeFrain et al., 2004) in diets for transition dairy cows, which represents 0.8 and $7.6 \%$ of ration DM, respectively. Studies conducted to date indicate a lack of difference in DM intake, health incidences, and milk production when glycerol is fed during the prepartum period (DeFrain et al., 2004; Chung et al., 2007). Recent studies indicate that glycerol can replace corn grain in diets for midlactation dairy cows to as much as $15 \%$ of the ration DM (Donkin et al., 2009). The effects of feeding greater levels of glycerol in place of corn in diets fed to transition cows has not been explored. Combined results of previous studies indicating a lack of negative effect of glycerol on intake or production indicate that glycerol may be a suitable energy source in diets of transition dairy cows. We hypothesized that glycerol could replace corn grain in diets for transition cows.

The objective of the present experiment was to determine the effects of replacing high-moisture corn with glycerol in diets for transition dairy cows on feed intake, metabolic and rumen parameters, and postpartum milk production. 


\section{MATERIALS AND METHODS}

\section{Cows and Dietary Treatments}

Twenty-six multiparous Holstein cows were paired by expected calving date and randomly assigned to receive either a diet containing corn silage, alfalfa haylage, hay, high-moisture corn, cotton seed hulls, soybean hulls, vitamins, and minerals (control) or a diet in which high-moisture ear corn was replaced with a mixture of glycerol and soybean meal (glycerol) beginning $28 \mathrm{~d}$ before expected calving through 56 DIM. Refined glycerol (99.5\% United States Pharmacopeia-grade glycerine; Pt Sumi Ashi Oleochemicals Industry, Jakarta, Indonesia) was included at 11.5 and $10.8 \%$ of the ration DM for their pre- and postpartum diets, respectively (Table 1). Soybean meal was added to the glycerol diets to adjust for the protein removed from the diet with high-moisture corn. Samples of TMR were collected weekly, dried in a forced-air oven for $72 \mathrm{~h}$ at $55^{\circ} \mathrm{C}$, and ground using a Wiley mill to pass a 1-mm screen. Composite samples were formed monthly and analyzed by a commercial laboratory (Dairy One, Ithaca, NY) for DM, CP, ADF, starch, and minerals by wet chemistry following AOAC (2000) procedures, and for NDF following the method of Goering and Van Soest (1970).

Cows were housed in individual tie stalls at the Purdue Dairy Research and Education Center (West Lafayette, IN) and fed diets formulated to meet or exceed the NRC (2001) guidelines for 600-kg dairy cattle. Diets were fed as a TMR once daily between 0630 to $0730 \mathrm{~h}$ in amounts that ensured ad libitum consumption and approximately 10 to $15 \%$ feed refusals. Cows were milked twice daily at approximately 0700 and $1830 \mathrm{~h}$. Animal use and handling protocols were approved by the Purdue Animal Care and Use Committee.

\section{Sample Collection and Analysis}

Feed refusals were measured daily and feed intake was determined by difference assuming a similar DM content of feed offered and feed refused. Milk yield was recorded daily; milk samples from individual cows were obtained weekly at 2 consecutive milkings, preserved with 2-bromo-2-nitropropane-1,3-diol, and analyzed for protein, fat, lactose, SCC, and total solids content by a commercial laboratory (Dairy One). Body weights and BCS were obtained at $-28,+1,+28$, and +56 $\mathrm{d}$ relative to calving. Body condition was scored by 2 trained individuals using a 5-point scale (Wildman et al., 1982) and scores were averaged for each cow within $1 \mathrm{~d}$ of observation. Blood samples were collected via venipuncture of the coccygeal vein or artery into evacuated tubes (Becton Dickinson, Franklin Lakes, NJ) and centrifuged at $3,000 \times g$ to separate plasma. Tubes $(6$
$\mathrm{mL}$ ) containing potassium oxalate and $4 \%$ of sodium fluoride were used for collection of plasma for analyses for glucose, NEFA, and BHBA. Tubes $(10 \mathrm{~mL})$ containing sodium heparin were used to collect plasma for analyses of glycerol. Blood samples were transported on ice to the laboratory and plasma separated within 1.5 $\mathrm{h}$ after sampling. Plasma samples were stored frozen at $-20^{\circ} \mathrm{C}$ until analyses for glucose (Wako Chemicals USA, Inc., Richmond, VA), based on the method of Trinder (1969), BHBA (Stanbio Laboratory Inc., Boerne, TX), based on the method of Williamson et al. (1962), NEFA (Wako NEFA C Kit; Biochemical Diagnostics Inc., Edgewood, NY), based on a method modified according to the procedure of Johnson and Peters (1993), and glycerol (Sigma-Aldrich, St. Louis, MO), based on the method of McGowan et al. (1983). Liver biopsy samples were collected on $\mathrm{d}-28,-14,+1,+14,+28$, and +56 relative to calving as described previously (Greenfield et al., 2000). Analysis of mRNA profiles and metabolites from these samples is not reported here.

\section{Rumen Fluid Sampling and Analysis}

Ruminal fluid from individual cows was collected by gentle aspiration through a tube fitted with a stainless steel strainer and extending through the esophagus into the rumen. Samples were collected from all cows between 3 to $4 \mathrm{~h}$ postfeeding on 56 DIM. The $\mathrm{pH}$ of rumen fluid was immediately measured and $2.5 \mathrm{~mL}$ of $25 \%$ metaphosphoric acid was added to $7.5 \mathrm{~mL}$ of rumen fluid and stored for VFA analyses. A separate sample was acidified with $1.5 \mathrm{~mL}$ of $6 \mathrm{~N}$ sulfuric acid per $23.5 \mathrm{~mL}$ of rumen fluid and stored pending rumen glycerol analyses.

Samples were analyzed for VFA by gas chromatography (model 7890A, Agilent Technologies, Santa Clara, $\mathrm{CA}$ ) and flame ionization detection, a Nukol capillary column (30 $\mathrm{m}$ in length, 0.25-mm i.d., 25- $\mu$ phase, Supelco, Inc., Bellefonte, PA) and 2-ethylbutyric acid as an internal standard. Oven temperature program was 90 to $150^{\circ} \mathrm{C}$ at $10^{\circ} \mathrm{C} / \mathrm{min}$, using helium carrier gas maintained at $17.1 \mathrm{kPa}$. The injector port was set at $270^{\circ} \mathrm{C}$ and split injections were made at a $30: 1$ split ratio. The flame ionization detector conditions were: temperature of $300^{\circ} \mathrm{C}$, air at $400 \mathrm{~mL} / \mathrm{min}$, and $\mathrm{H}_{2}$ at 40 $\mathrm{mL} / \mathrm{min}$ with makeup He flow at $26 \mathrm{~mL} / \mathrm{min}$. Concentrations of VFA were determined from comparison with a VFA standard solution (Sigma-Aldrich). Rumen fluid samples were analyzed for glycerol content using the free glycerol determination kit (Sigma-Aldrich).

\section{Data Analysis}

The data were analyzed using the MIXED procedure of SAS (SAS Institute, 1999). The model accounted for 
the effects of treatment, time (as either DIM or week of experiment), and the interaction of treatment by time (as DIM or week). Compound symmetry covariance structure was used to evaluate variables measured. Feed intake, milk production, and feed efficiency were analyzed with repeated measures by DIM. Average weekly milk production, feed intake, feed efficiency, milk composition, and energy balance were analyzed using repeated measures by week. Means were different if $P<0.05$ and tended to differ if $0.05 \leq P \leq 0.15$. Values reported are least squares means and associated standard errors.

\section{RESULTS}

Twenty-three cows completed the study. One cow from the control group and 1 cow from the glycerol group were removed due to a displaced abomasum, and 1 cow from the control group was removed due to uterine torsion that occurred $7 \mathrm{~d}$ before parturition. Data reported are for 12 cows in the glycerol group and 11 cows in the control group.

Cows fed glycerol had similar daily feed intake during the prepartum and postpartum period as did cows fed the control (Table 2). A treatment $\times$ week effect was

Table 1. Ingredient and nutrient composition of the pre- and postpartum experimental diets

\begin{tabular}{|c|c|c|c|c|}
\hline \multirow[b]{2}{*}{ Item } & \multicolumn{2}{|c|}{ Prepartum } & \multicolumn{2}{|c|}{ Postpartum } \\
\hline & Control & Glycerol & Control & Glycerol \\
\hline \multicolumn{5}{|l|}{ Ingredient, $\%$ of $\mathrm{DM}$} \\
\hline Corn silage & 35.4 & 35.4 & 39.0 & 39.0 \\
\hline Alfalfa haylage & 8.0 & 8.0 & 15.5 & 15.5 \\
\hline Grass hay & 13.0 & 13.0 & 3.5 & 3.5 \\
\hline Wheat straw & - & - & 1.5 & 1.5 \\
\hline Cotton seed hulls & 6.0 & 6.0 & - & - \\
\hline Soybean hulls & 7.8 & 7.8 & 2.0 & 2.0 \\
\hline High-moisture corn & 14.0 & 然 & 12.5 & \\
\hline Glycerol & - & 11.5 & - & 10.8 \\
\hline Soybean meal & - & 2.5 & 10.0 & 11.0 \\
\hline Megalac $\mathrm{R}^{1}$ & - & - & 0.7 & 0.7 \\
\hline Protein blend ${ }^{2}$ & - & - & 5.3 & 6.0 \\
\hline Supplement ${ }^{3,4}$ & 15.8 & 15.8 & 10.0 & 10.0 \\
\hline \multicolumn{5}{|l|}{ Chemical composition $^{5}$} \\
\hline DM, \% & 50.9 & 49.4 & 46.8 & 46.0 \\
\hline $\mathrm{CP}, \%$ of DM & $16.6(1.00)$ & $16.6(1.35)$ & $18.2(0.83)$ & $18.7(1.00)$ \\
\hline $\mathrm{ADF}, \%$ of $\mathrm{DM}$ & $22.9(1.75)$ & $25.5(1.79)$ & $19.5(1.77)$ & $20.8(2.32)$ \\
\hline NDF, $\%$ of DM & $38.0(1.18)$ & $42.2(1.35)$ & $31.4(2.71)$ & $34.2(1.67)$ \\
\hline Starch, \% of DM & $22.6(2.64)$ & $15.0(1.22)$ & $26.7(1.73)$ & $19.2(1.12)$ \\
\hline $\mathrm{NE}_{\mathrm{L}}, \mathrm{Mcal} / \mathrm{kg}$ of DM & $1.58(0.02)$ & $1.61(0.05)$ & $1.65(0.02)$ & $1.61(0.02)$ \\
\hline $\mathrm{Ca}, \%$ of $\mathrm{DM}$ & $1.09(0.17)$ & $1.02(0.12)$ & $1.11(0.07)$ & $1.11(0.20)$ \\
\hline $\mathrm{P}, \%$ of $\mathrm{DM}$ & $0.36(0.02)$ & $0.34(0.02)$ & $0.43(0.02)$ & $0.40(0.04)$ \\
\hline $\mathrm{Mg}, \%$ of $\mathrm{DM}$ & $0.39(0.04)$ & $0.36(0.02)$ & $0.36(0.04)$ & $0.35(0.02)$ \\
\hline $\mathrm{K}, \%$ of DM & $1.22(0.05)$ & $1.29(0.09)$ & $1.47(0.11)$ & $1.44(0.03)$ \\
\hline $\mathrm{Na}, \%$ of $\mathrm{DM}$ & $0.15(0.01)$ & $0.15(0.01)$ & $0.32(0.01)$ & $0.32(0.02)$ \\
\hline
\end{tabular}

${ }^{1}$ Church \& Dwight Co. Inc., Princeton, NJ.

${ }^{2}$ Contained $44 \%$ of Aminoplus (Archer Daniels Midland Co., Decatur, IL), 3\% of menhaden fish meal, $53 \%$ of ProvAAL STD 5000 (ProvAAL, Salisbury, MD).

${ }^{3}$ Prepartum: contained $38.29 \%$ soybean meal, $25.65 \%$ Bio-Chlor (Church \& Dwight Co. Inc.), 5.4\% $\mathrm{CaCO}_{3}$, $2.16 \%$ dicalcium phosphate, $1.08 \% \mathrm{MgO}, 1.08 \% \mathrm{NaCl}, 1.65 \%$ mineral/vitamin premix $(16.11 \% \mathrm{Ca}, 2.11 \% \mathrm{~S}$, $31,505 \mathrm{mg}$ of $\mathrm{Zn} / \mathrm{kg}, 8,036 \mathrm{mg}$ of $\mathrm{Cu} / \mathrm{kg}, 26,020 \mathrm{mg}$ of Mn $/ \mathrm{kg}, 140 \mathrm{mg}$ of Se $/ \mathrm{kg}, 473 \mathrm{mg}$ of Co/kg, $284 \mathrm{mg}$ of I/ $\mathrm{kg}, 1,440 \mathrm{kIU} / \mathrm{kg}$ vitamin A, $416 \mathrm{kIU} / \mathrm{kg}$ vitamin D, 6,647 $\mathrm{IU} / \mathrm{kg}$ vitamin E), $2.16 \% \mathrm{MgSO}_{4}, 5.08 \%$ Megalac R (Church \& Dwight Co. Inc.), 0.49\% niacinamide (99.5\% niacin), 2.62\% yeast culture (Diamond V Mills, Cedar Rapids, IA), $1.8 \%$ vitamin E 20,000, $0.08 \%$ of Rumensin 80 (Elanco Animal Health, Greenfield, IN), $2.62 \%$ Omnigen-AF (Prince-Agri Products, Quincy, IL), 1.08\% urea, 4.38\% blood meal, 3.81\% Aminoplus (Archer Daniels Midland Co.), $0.57 \%$ menhaden fish meal.

${ }^{4}$ Postpartum: contained $25 \%$ dried molasses, $42.75 \%$ finely ground corn, $7.5 \% \mathrm{CaCO}_{3}, 5 \%$ of dicalcium phosphate, $6.2 \% \mathrm{NaHCO}_{3}, 2 \% \mathrm{MgO}, 2 \%$ DCAD Plus (Arm \& Hammer Animal Nutrition, Church \& Dwight Co. Inc.), $0.5 \%$ potassium magnesium sulfate, $2.5 \% \mathrm{NaCl}, 2.025 \%$ of mineral/vitamin premix $(16.11 \% \mathrm{Ca}, 2.11 \% \mathrm{~S}$, $31,505 \mathrm{mg}$ of $\mathrm{Zn} / \mathrm{kg}, 8,036 \mathrm{mg}$ of $\mathrm{Cu} / \mathrm{kg}, 26,020 \mathrm{mg}$ of $\mathrm{Mn} / \mathrm{kg}, 140 \mathrm{mg}$ of Se/kg, $473 \mathrm{mg}$ of Co/kg, $284 \mathrm{mg}$ of $\mathrm{I} / \mathrm{kg}, 1,440 \mathrm{kIU} / \mathrm{kg}$ vitamin $\mathrm{A}, 416 \mathrm{kIU} / \mathrm{kg}$ vitamin $\mathrm{D}, 6,647 \mathrm{IU} / \mathrm{kg}$ vitamin $\mathrm{E}$ ), $0.25 \%$ niacinamide (99.5\% niacin), $2 \%$ yeast culture (Diamond V Mills), $0.213 \%$ of vitamin E 20,000, 0.062\% Rumensin 80 (Elanco Animal Health), 2\% Omnigen-AF (Prince-Agri Products).

${ }^{5}$ Mean analysis for composite samples $(\mathrm{n}=5)$ and associated standard deviations (values in parentheses). 


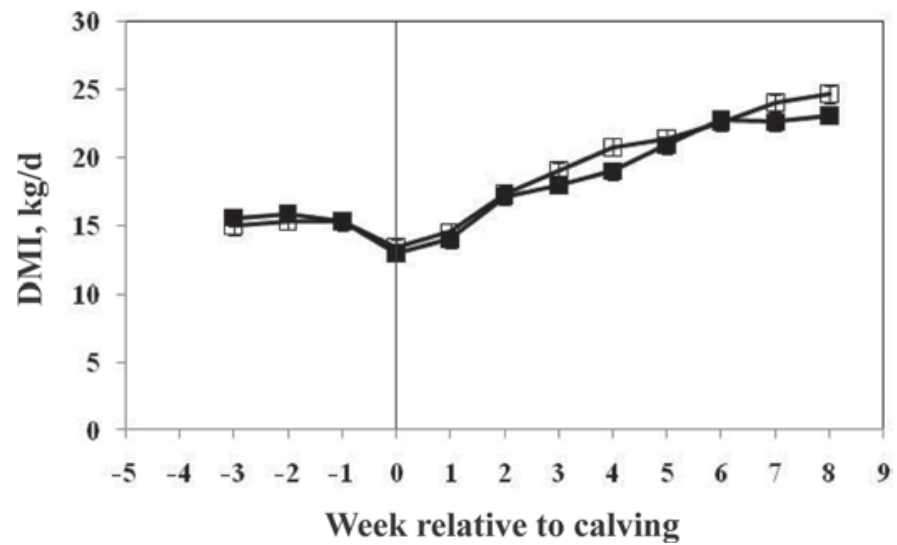

Figure 1. Dry matter intake $(\mathrm{kg} / \mathrm{d})$ of transition dairy cows fed control (solid squares) or glycerol (open squares) diet during the preand postpartum intervals.

observed for intake during the prepartum period that appears to be due to reduced intake for the glycerol-fed cows during the first $10 \mathrm{~d}$ of the trial (Figure 1), and a tendency $(P=0.09)$ for a treatment $\times$ week effect on feed intake over the entire experiment also was found. Average milk yield, $4 \%$ fat-corrected milk yield, and feed efficiency were not altered $(P>0.05)$ by glycerol feeding (Table 2$)$, but a tendency $(P<0.15)$ existed for a treatment $x$ week effect on milk yield due to greater milk production during the last $14 \mathrm{~d}$ of the trial for cows fed glycerol (Figure 2). Likewise, a treatment $\times$ week tendency $(P<0.15)$ for feed efficiency was observed. No main effects $(P>0.05)$ of diet on milk composition existed (Table 2$)$ but a tendency $(P<0.15)$ was noted for a treatment $\times$ week effect for milk protein due to greater production for the glycerol-fed cows during the last $14 \mathrm{~d}$ of the trial.

Initial BW was $688.5 \pm 67.5 \mathrm{~kg}$ and $718.4 \pm 83.6 \mathrm{~kg}$ for cows fed the control and glycerol diets, respectively, and BW change did not differ $(P>0.05)$ between treatments at any time before or after calving. The mean BW for both groups was $703.4 \pm 15.1$ at calving, $609 \pm$ 15.1 at +28 DIM, and $614 \pm 15.1$ at +56 DIM. Initial $\mathrm{BCS}$ was $2.64 \pm 0.17$ and $2.69 \pm 0.19$ for the control and glycerol groups, respectively, and no differences due to treatment across during the pre- or postpartum period were observed.

Cows fed glycerol had lower $(P<0.05)$ mean blood glucose concentrations for the entire experimental period. When the analysis was separated into pre- and postcalving intervals, blood glucose concentration was decreased $(P<0.05)$ during the prepartum interval, and a tendency $(P=0.10)$ of blood glucose concentration to decrease existed during the postpartum interval for

Table 2. Effect of glycerol on feed intake, milk production, milk composition, feed efficiency, BW change, and BCS change

\begin{tabular}{|c|c|c|c|c|c|c|}
\hline \multirow[b]{2}{*}{ Item } & \multicolumn{2}{|c|}{ Treatment } & \multirow[b]{2}{*}{ SEM } & \multicolumn{3}{|c|}{$P$-value } \\
\hline & Control & Glycerol & & $\operatorname{Trt}^{1}$ & Time $^{2}$ & Trt $\times$ time \\
\hline \multicolumn{7}{|l|}{ DMI, kg/d } \\
\hline Prepartum 3 & 14.9 & 14.6 & 0.44 & 0.62 & $<0.05$ & $<0.05$ \\
\hline Postpartum ${ }^{4}$ & 19.8 & 20.7 & 0.51 & 0.24 & $<0.05$ & 0.47 \\
\hline Pre- and postpartum ${ }^{5}$ & 18.2 & 18.6 & 0.43 & 0.47 & $<0.05$ & 0.09 \\
\hline Milk yield, $\mathrm{kg} / \mathrm{d}$ & 35.8 & 37.0 & 1.45 & 0.56 & $<0.05$ & 0.15 \\
\hline \multicolumn{7}{|l|}{ Milk composition } \\
\hline $4 \% \mathrm{FCM}, \mathrm{kg} / \mathrm{d}$ & 35.3 & 36.7 & 1.67 & 0.56 & $<0.05$ & 0.88 \\
\hline Milk:DMI, $\mathrm{kg} / \mathrm{kg}$ & 1.84 & 1.83 & 0.05 & 0.85 & $<0.05$ & 0.43 \\
\hline Milk fat, $\%$ & 4.01 & 4.00 & 0.12 & 0.95 & $<0.05$ & 0.41 \\
\hline Milk fat, $\mathrm{kg} / \mathrm{d}$ & 1.41 & 1.46 & 0.08 & 0.65 & 0.20 & 0.80 \\
\hline Milk protein. \% & 2.93 & 2.90 & 0.05 & 0.65 & $<0.05$ & 0.15 \\
\hline Milk protein, $\mathrm{kg} / \mathrm{d}$ & 1.02 & 1.06 & 0.04 & 0.52 & 0.09 & 0.09 \\
\hline Milk lactose. \% & 4.72 & 4.69 & 0.02 & 0.28 & 0.14 & 0.39 \\
\hline Milk lactose, $\mathrm{kg} / \mathrm{d}$ & 1.67 & 1.73 & 0.07 & 0.59 & $<0.05$ & 0.75 \\
\hline Milk solids, \% & 12.55 & 12.44 & 0.15 & 0.60 & $<0.05$ & 0.31 \\
\hline Milk solids, $\mathrm{kg} / \mathrm{d}$ & 4.42 & 4.57 & 0.20 & 0.60 & $<0.05$ & 0.86 \\
\hline $\mathrm{SCC}, \times 1,000$ cells $/ \mathrm{mL}$ & 429 & 624 & 287.7 & 0.64 & 0.32 & 0.07 \\
\hline MUN, mg/dL & 16.01 & 14.94 & 0.63 & 0.24 & 0.39 & 0.84 \\
\hline BW change, $\mathrm{kg}$ & -73.7 & -69.4 & 6.63 & 0.64 & $<0.05$ & $\begin{array}{l}0.04 \\
0.95\end{array}$ \\
\hline BCS change ${ }^{6}$ & -0.18 & -0.19 & 0.03 & 0.80 & $<0.05$ & 0.94 \\
\hline
\end{tabular}

${ }^{1}$ Treatment.

${ }^{2}$ Days relative to calving.

${ }^{3}$ Data for $28 \mathrm{~d}$ prepartum through calving.

${ }^{4}$ Data for 1 through 56 DIM.

${ }^{5}$ Combined data -28 through 56 DIM.

${ }^{6}$ Cows were scored at $-28,1,28$, and 56 DIM. Values represent average change from BCS at -28 DIM. 
Table 3. Effect of glycerol on plasma metabolites

\begin{tabular}{|c|c|c|c|c|c|c|}
\hline \multirow[b]{2}{*}{ Item } & \multicolumn{2}{|c|}{ Treatment } & \multirow[b]{2}{*}{ SEM } & \multicolumn{3}{|c|}{$P$-value } \\
\hline & Control & Glycerol & & $\operatorname{Trt}^{1}$ & Time $^{2}$ & Trt $\times$ time \\
\hline \multicolumn{7}{|l|}{ Glucose, mg/dL } \\
\hline Prepartum 3 & 59.1 & 53.4 & 1.61 & $<0.05$ & $<0.05$ & 0.11 \\
\hline Postpartum ${ }^{4}$ & 53.6 & 50.8 & 1.15 & 0.10 & $<0.05$ & 0.63 \\
\hline Pre- and postpartum ${ }^{5}$ & 56.5 & 52.5 & 1.00 & $<0.05$ & $<0.05$ & 0.21 \\
\hline \multicolumn{7}{|l|}{ NEFA, mmol/L } \\
\hline Prepartum & 0.22 & 0.18 & 0.02 & 0.22 & $<0.05$ & 0.13 \\
\hline Postpartum & 0.50 & 0.41 & 0.04 & 0.14 & $<0.05$ & 0.62 \\
\hline Pre- and postpartum & 0.35 & 0.29 & 0.02 & 0.07 & $<0.05$ & 0.60 \\
\hline \multicolumn{7}{|l|}{$\mathrm{BHBA}, \mathrm{mmol} / \mathrm{L}$} \\
\hline Prepartum & 0.58 & 0.82 & 0.04 & $<0.05$ & 0.07 & 0.82 \\
\hline Postpartum & 0.77 & 0.94 & 0.07 & 0.09 & $<0.05$ & 0.49 \\
\hline Pre- and postpartum & 0.66 & 0.87 & 0.04 & $<0.05$ & $<0.05$ & 0.75 \\
\hline \multicolumn{7}{|l|}{ Glycerol, mg/dL } \\
\hline Prepartum & 0.64 & 0.82 & 0.14 & 0.32 & 0.05 & 0.75 \\
\hline Postpartum & 0.91 & 0.61 & 0.17 & 0.22 & 0.05 & 0.55 \\
\hline Pre- and postpartum & 0.75 & 0.74 & 0.11 & 0.91 & 0.02 & 0.60 \\
\hline
\end{tabular}

cows fed glycerol (Table3, Figure 3). Also, a tendency $(P<0.15)$ of decrease in blood NEFA concentration was present during the combined pre- and postpartum intervals for cows fed glycerol (Table 3 and Figure 3). Overall blood BHBA concentration was increased $(P$ $<0.05)$ for cows fed glycerol and no time $\times$ treatment effects were found.

Ruminal $\mathrm{pH}$ and glycerol concentration in the rumen were not influenced by treatments (Table 4). Likewise, total rumen VFA concentration did not differ between treatments, but rumen propionate, butyrate, and valerate concentrations (expressed as percentages of total VFA) were greater $(P<0.05)$ for cows fed glycerol, at the expense of acetate and isobutyrate. Cows fed glycerol had a decreased $(P<0.05)$ acetate to propionate ratio (Table 4).

\section{DISCUSSION}

Ongoing increases in the production of biofuels has led to a supply of glycerol that may not be absorbed by the pharmaceutical and chemical industries, therefore creating an opportunity to use glycerol as an energy source in rations fed to dairy cattle. Previous research examining the potential for glycerol as a feed for dairy cattle indicates that as much as $15 \%$ of the ration DM can be fed as glycerol to midlactation dairy cows. The onset of lactation poses considerable challenges to the dairy cow because feed intake often lags behind energy needs and feeding management strategies must consider the effect of feeds on intake and health status. Previous research indicates a mixed response to glycerol feeding in transition cows (DeFrain et al., 2004; Bodarski et al., 2005; Chung et al., 2007). Top dressing with glycerol up to $7.6 \%$ of ration DM resulted in a decrease in feed intake during the prepartum interval, but this effect disappeared after parturition (DeFrain et al., 2004). In contrast, feeding 300 or $500 \mathrm{~mL}$ of glycerol from -14 to +70 DIM had no effect on feed intake during the prepartum interval but increased feed intake between +35 and +63 DIM (Bodarski et al., 2005). A recent study (Chung et al., 2007) to evaluate the effects of feeding a dry glycerin product from calving to $+21 \mathrm{~d}$ postpartum indicated no effect of glycerin on feed intake. Liquid

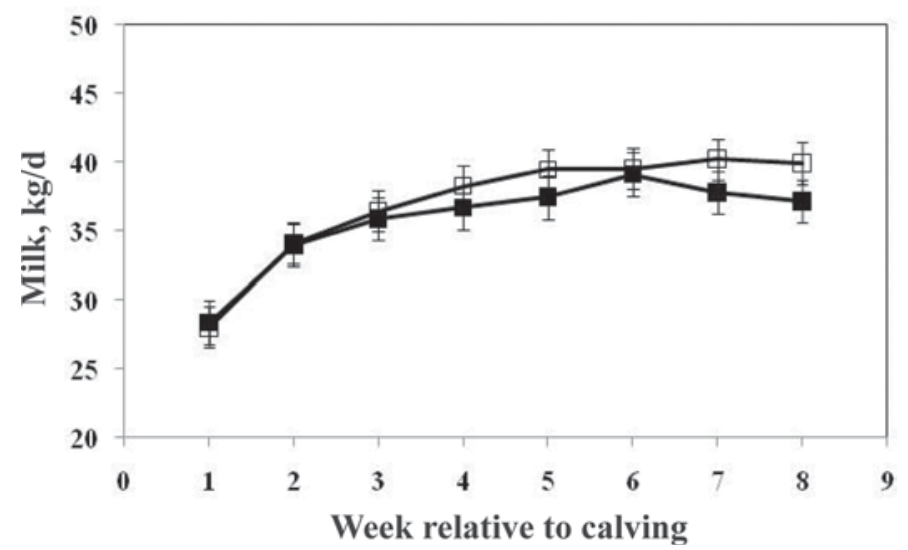

Figure 2. Milk yield $(\mathrm{kg} / \mathrm{d})$ of transition dairy cows fed the the control (solid squares) or glycerol (open squares) diet during the preand postpartum intervals. 

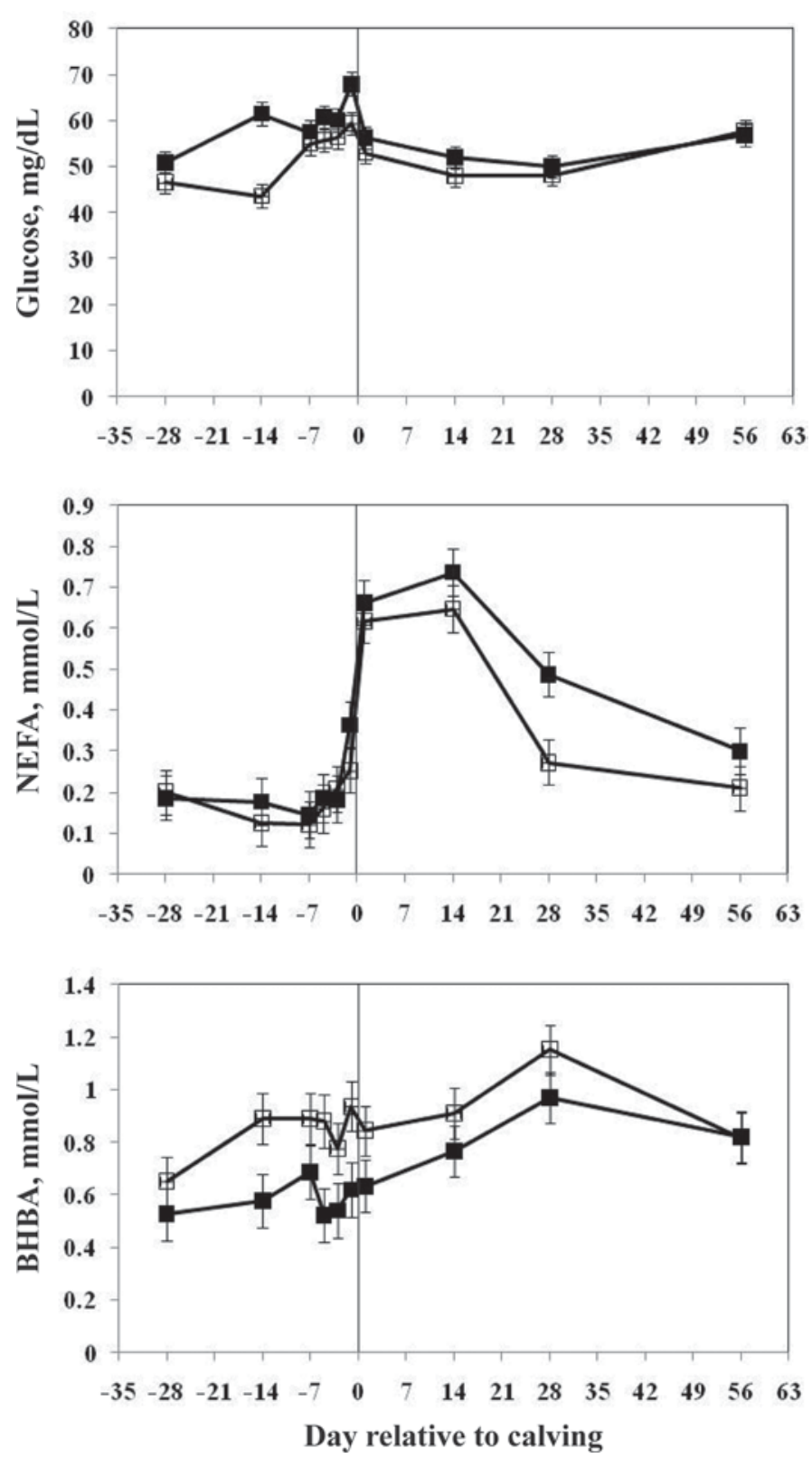

Figure 3. Effect of glycerol on glucose, NEFA, and BHBA in plasma for cows fed the glycerol (open squares) or control diet (solid squares).

glycerol from biodiesel processing may contain a variety of contaminants, including water, salts, and methanol (Thompson and He, 2006), and the crude biodiesel glycerol used by DeFrain et al. (2004) contained $80.2 \%$ glycerol, $11.5 \%$ salt, $6.6 \%$ water, and $1.3 \%$ methanol. Adding crude glycerol containing $85.7 \%$ glycerol, $5.5 \%$ salts, and $0.09 \%$ methanol to $10 \%$ of ration DM had no detrimental effect on intake and performance of beef cattle (Mach et al., 2009). The presence of contaminants in any feeds, including glycerol, clouds the interpretation of feeding experiments; therefore, we used food-grade glycerol in the present experiment to eliminate any possible confounding effects of impurities on DMI, production, or health. The present data indicate that glycerol can replace corn in the diet of transition cows to at least $11.5 \%$ of ration $\mathrm{DM}$ without compromising intake during the pre- or postpartum intervals. Previous studies indicate that feeding $15 \%$ glycerol to midlactation dairy cows may be accompanied by a transient decrease in feed intake but a similar temporary decrease in intake was not observed when $10 \%$ glycerol was fed (Donkin et al., 2009). Although there is debate regarding optimal levels of fermentable energy for transition dairy cows (Overton and Waldron, 2004), the data reported here indicates that glycerol provides an alternative energy source for use in transition cow rations that does not negatively affect intake. Additional studies are needed to determine the effects of glycerol at levels in excess of $11.5 \%$ of DM in diets for transition cows.

Milk production was similar for cows fed the glycerol and the control diet. A tendency was present for a treatment $\times$ week effect on milk production that favored glycerol feeding during the fourth, fifth, and seventh week of lactation. The lack of effect of glycerol on average milk production for the 56-d experiment agrees with findings from previous studies in which transition cows were fed glycerol (DeFrain et al., 2004; Chung et al., 2007) but differs from results from studies in which there was supplementation of 300 or $500 \mathrm{~mL}$ of glycerol as a topdress fed to dairy cows once daily from 2 wk before calving through 10 wk of lactation. In the latter experiments, glycerol increased milk production by approximately $4.7 \mathrm{~kg} / \mathrm{d}$ compared with that from cows fed a control diet (Bodarski et al., 2005). Chung et al. (2007) observed a tendency for carryover effects of glycerol to increase milk production. We also examined milk production for $56 \mathrm{~d}$ after cows were released from the present study but failed to observe any similar effect, despite a time $\times$ treatment effect on milk production that suggests a tendency for increased milk production during the last $10 \mathrm{~d}$ of trial for cows fed glycerol.

Cows fed glycerol had a tendency for reduced blood NEFA concentrations across the entire study but had increased blood BHBA concentrations. The former suggests either an increased capacity to metabolize NEFA or a decreased release of NEFA from adipose tissue. The observed increases in BHBA concentrations suggest increased appearance of BHBA from either partial oxidation of NEFA, increased production by rumen epithelium in the metabolism of butyrate, or both, that is in excess of the capacity of extrahepatic tissue to utilize ketones. An increase in fatty acid clearance by liver in response to glycerol in diets for transition cows would 
Table 4. Effect of glycerol on rumen parameters ${ }^{1}$

\begin{tabular}{lcccc}
\hline Item & Control & Glycerol & SE & $P$-value \\
\hline $\mathrm{pH}$ & 7.08 & 6.94 & 0.13 & 0.44 \\
Glycerol, $\mathrm{mg} / \mathrm{mL}$ & 0.08 & 0.07 & 0.01 & 0.81 \\
Total VFA, mmol/L & 82.3 & 85.9 & 6.52 & 0.70 \\
Individual VFA, \% of total VFA & & & & \\
Acetate (A) & 61.4 & 51.5 & 1.08 & $<0.05$ \\
Propionate (P) & 22.7 & 28.6 & 1.44 & $<0.05$ \\
Isobutyrate & 1.11 & 0.92 & 0.05 & $<0.05$ \\
Butyrate & 1.5 & 15.3 & 0.71 & $<0.05$ \\
Isovalerate & 1.84 & 1.64 & 0.07 & 0.07 \\
Valerate & 1.48 & 2.06 & 0.06 & $<0.05$ \\
A:P ratio & 2.76 & 1.88 & 0.14 & $<0.05$ \\
\hline
\end{tabular}

${ }^{1}$ From samples collected 3 to $4 \mathrm{~h}$ postfeeding on 56 DIM.

support a decrease in liver lipid concentration at calving. The decrease in NEFA concentration observed in the present study is consistent with the early postpartum response to glycerol observed previously (DeFrain et al., 2004; Bodarski et al., 2005) but is in conflict with the lack of response in NEFA concentration observed in other experiments in which glycerol was fed as a topdress (Chung et al., 2007) or included in drinking water (Osborne et al., 2009). Increased BHBA concentration has been consistently observed for transition cows fed glycerol (DeFrain et al., 2004; Chung et al., 2007; Osborne et al., 2009). Previous experiments indicate that both feeding and drenching with glycerol increase ruminal butyrate and plasma BHBA concentrations (Linke et al., 2004). The present data indicate a shift in rumen metabolism, resulting in greater butyrate concentrations. The root cause of increased BHBA concentration in plasma with glycerol feeding cannot be determined without additional physiological measures, given that ruminal butyrate concentrations do not accurately reflect production rates (Firkins et al., 2006). However, due to the role of butyrate in ketogenesis (Bergman, 1990), caution should be exercised when using glycerol in transition cow diets because an increase in BHBA concentration in blood can be accompanied by decreased feed intake and undesirable metabolic consequences. However, it should be noted that none of the cows fed glycerol in the current study had BHBA concentrations in excess of $1.4 \mathrm{mmol} / \mathrm{L}$, which has been described as a threshold value for subclinical ketosis in early-lactation cows (Duffield, 2000). Furthermore, no negative effects of glycerol on feed intake or milk production were detected in this study.

Cows fed glycerol experienced a decrease in blood glucose concentration during the prepartum interval, which persisted through +14 DIM. These data differ from those of previous work indicating that blood glucose concentration increased when glycerol was drenched (Goff and Horst, 2001; Linke et al., 2004), fed to midlactation cows, or used as a topdress supplement (Bodarski et al., 2005; Chung et al., 2007). A similar tendency for decreased blood glucose concentration in response to glycerol feeding has been observed previously for transition cows (DeFrain et al., 2004). The effect of glycerol on blood glucose concentration is similar in magnitude, although opposite in direction, to the change in blood glucose concentration for transition cows fed diets containing monensin, where blood glucose and energy intake have been linked (Plaizier et al., 2005).

Because blood glucose concentration is a function of the rates of glucose absorption, glucose production, and glucose utilization, it is difficult to determine the mechanism of glycerol action without additional physiological measures. However, the lack of overall differences in milk production, BW change, and BCS change do not support differences in glucose utilization. Gluconeogenesis from propionate is impaired by the presence of butyrate (Aiello and Armentano, 1987). Normally, butyrate is extensively metabolized to BHBA by rumen epithelium; however, under some conditions, the capacity for butyrate metabolism by rumen epithelium can be compromised (Kristensen and Harmon, 2004). An increase in rumen butyrate concentrations in the present study, if linked to butyrate absorption in excess of rumen epithelial metabolism, could increase the supply of butyrate to liver and, consequently, decrease hepatic gluconeogenesis from propionate. However, the metabolic capacity of the rumen epithelium to metabolize butyrate to BHBA can also be adapted by increasing butyrate loads (Sehested et al., 1999); therefore, feeding glycerol might induce an adaptation of the metabolic capacity of the ruminal epithelium. The present data indicate that the greatest reduction in plasma glucose concentration occurred within $14 \mathrm{~d}$ after the initiation of glycerol feeding. Several weeks are necessary to adapt the absorptive capacity of the rumen to increased grain in the diet (Dirksen et al., 1985). Adaptation of rumen 
epithelium to enhance butyrate oxidation and decrease flux of butyrate to liver is consistent with a recovery of glucose to control values at calving. Additional experiments are necessary to determine the effect of glycerol feeding on rumen butyrate production rates, and postabsorptive butyrate metabolism.

Glycerol in this study was administered as part of the TMR and, therefore, was subject to rumen fermentation. Glycerol that is orally drenched appears to be more effective in stimulating blood glucose levels than is glycerol that is fed (Goff and Horst, 2001; Linke et al., 2004) or supplied in drinking water (Osborne et al., 2009). Postruminal flow of glycerol and direct ruminal glycerol absorption of glycerol has not been examined directly for ruminants when glycerol has been fed, drenched, or supplied in drinking water. However, when glycerol is added directly to the rumen only one-half of ruminal disappearance can be accounted for by bacterial fermentation, which suggests either direct absorption of glycerol across the rumen wall (Rémond et al., 1993) or postruminally. Because the density of glycerol (1.26 $\mathrm{g} / \mathrm{mL}$ ) closely matches the optimal density for passage of particles from the rumen (Neel et al., 1995), it is likely that glycerol delivered as a drench may escape the rumen. Likewise, because 18 to $80 \%$ of ingested water bypasses the rumen (Woodford et al., 1984), glycerol added to drinking water would be expected to escape rumen fermentation. In previous experiments the addition of glycerol to drinking water did not alter milk production in transition cows because the energy provided by glycerol in drinking water was offset by a decrease in energy intake from the TMR (Osborne et al., 2009). Observed differences in physiological responses to glycerol as a primary feed ingredient, as an oral drench, or added to drinking water are likely a consequence of the effect of differences in metabolism due to direct absorption of glycerol and effects of glycerol fermentation in the rumen.

Data reported here and elsewhere (Donkin et al., 2009) indicate that glycerol can effectively replace corn grain in diets for dairy cattle and results in equal or slightly enhanced lactation performance. If corn grain is added primarily as a fermentable energy source then the breakeven substitution price of glycerol can be determined from the NFC content of corn grain. Given that corn grain is $88.1 \%$ of DM, $9.4 \%$ of protein, $9.5 \%$ of NDF, $4.2 \%$ of ether extract, $1.5 \%$ ash, and $75.4 \%$ of NFC (NRC, 2001) the glycerol breakeven substitution price on a DM basis (DMB) by this method is 0.754 multiplied by the value of corn grain (DMB). Alternatively, the substitution price of glycerol for corn could also be calculated by accounting for the value of protein, fiber, and oil that is lost when corn is removed from the diet and replaced with glycerol. By this method, the glycerol breakeven substitution price $=$ corn price $-($ protein price $\times 0.094)-($ fat price $\times 0.042)-(\mathrm{NDF}$ price $\times 0.095)$, where all feeds are valued on a DMB. More elegant alternatives are also available to determine glycerol breakeven price, which consider the price of all feedstuffs traded in a given market (St-Pierre and Glamocic, 2000). The cost of utilizing glycerol in diets for dairy cattle should also account for the cost of handling glycerol and any additional value of glycerol on eating behaviors and health of transition cows. Furthermore, the value of biodiesel glycerin for dairy cattle should account for the presence of any contaminants, including water, protein, fat, and minerals (Thompson and He, 2006) and their effects on productive efficiency and health.

\section{CONCLUSIONS}

Glycerol can be recommended to replace corn in rations fed to transition dairy cows up to 11.5 and $10.8 \%$ of the pre- and postpartum rations DM, respectively, based on the lack of detrimental effects on feed intake, milk production, or milk composition. Decreased glucose and elevated BHBA concentrations in blood suggest that additional information is needed to fully assess the metabolic status of transition cows fed glycerol.

\section{ACKNOWLEDGMENTS}

The authors acknowledge the support of Archer Daniels Midland Company for the generous gift of glycerol for this project, the help afforded them by M. Grott, manager at the Purdue Dairy Research Center, the Purdue Dairy Research and Education Center staff (West Lafayette, IN), and the laboratory expertise of S. Koser (Purdue University Department of Animal Sciences). This project was supported by the Agricultural Food Research Initiative of the National Institute of Food and Agriculture, USDA, Grant \# 2007-5561818237. Scholarship support for E. R. Carvalho was from Coordenação de Aperfeiçoamento de Pessoal de Nível Superior (CAPES), Ministério da Educação, Brasil.

\section{REFERENCES}

Aiello, R. J., and L. E. Armentano. 1987. Effects of volatile fatty acids on propionate metabolism and gluconeogenesis in caprine hepatocytes. J. Dairy Sci. 70:2504-2510.

AOAC. 2000. Official Methods of Analysis. 17th ed. AOAC Int., Gaithersburg, MD.

Bergman, E. N. 1990. Energy contributions of volatile fatty acids from the gastrointestinal tract in various species. Physiol. Rev. 70:567-590.

Bodarski, R., T. Wertelecki, F. Bommer, and S. Gosiewski. 2005. The changes of metabolic status and lactation performance in dairy cows under feeding TMR with glycerin (glycerol) supplement at periparturient period. Electronic Journal of Polish Agricultural 
Universities. http://www.ejpau.media.pl/volume8/issue4/art-22. html

Chung, Y. H., D. E. Rico, C. M. Martinez, T. W. Cassidy, V. Noirot, A. Ames, and G. A. Varga. 2007. Effects of feeding dry glycerin to early postpartum Holstein dairy cows on lactational performance and metabolic profiles. J. Dairy Sci. 90:5682-5691.

DeFrain, J. M., A. R. Hippen, K. F. Kalscheur, and P. W. Jardon. 2004. Feeding glycerol to transition dairy cows: Effects on blood metabolites and lactation performance. J. Dairy Sci. 87:41954206.

Dirksen, G. U., H. G. Liebich, and E. Mayer. 1985. Adaptive changes of the ruminal mucosa and their functional and clinical significance. Bovine Pract. 20:116-120.

Donkin, S. S., S. L. Koser, H. M. White, P. H. Doane, and M. J. Cecava. 2009. Feeding value of glycerol as a replacement for corn grain in rations fed to lactating dairy cows. J. Dairy Sci. 92:51115119.

Duffield, T. 2000. Subclinical ketosis in lactating dairy cattle. Vet. Clin. North Am. Food Anim. Pract. 16: 231-253.

FDA. 2006. Code of Federal Regulations, 21 CFR 582.1320, Title 21, Vol. 6, 21CFR582.1320. http://edocket.access.gpo.gov/cfr_2002/ aprqtr/21cfr582.1320.htm

Firkins, J. L., A. N. Hristov, M. B. Hall, G. A. Varga, and N. R. StPierre. 2006. Integration of ruminal metabolism in dairy cattle. J. Dairy Sci. 89(E. Suppl.):E31-E51.

Fisher, L. J., J. D. Erfle, and F. D. Sauer. 1971. Preliminary evaluation of the addition of glucogenic materials to the rations of lactating cows. Can. J. Anim. Sci. 51:721-727.

Goering, H. K., and P. J. Van Soest. 1970. Forage Fiber Analysis (Apparatus, Reagents, Procedures and Some Applications). Agric. Handbook No. 379. ARS-USDA, Washington, DC.

Goff, J. P., and R. L. Horst. 2001. Oral glycerol as an aid in the treatment of ketosis/fatty liver complex. J. Dairy Sci. 84(Suppl. 1):153. (Abstr.)

Greenfield, R. B., M. J. Cecava, and S. S. Donkin. 2000. Changes in mRNA expression for gluconeogenic enzymes in liver of dairy cattle during the transition to lactation. J. Dairy Sci. 83:1228-1236.

Johnson, M. M., and J. P. Peters. 1993. Technical note: An improved method to quantify nonesterified fatty acids in bovine plasma. J. Anim. Sci. 71:753-756.

Johnson, R. B. 1954. The treatment of ketosis with glycerol and propylene glycol. Cornell Vet. 44:6-21.

Kristensen, N. B., and D. L. Harmon. 2004. Effect of increasing ruminal butyrate absorption on splanchnic metabolism of volatile fatty acids absorbed from the washed reticulorumen of steers. J. Anim. Sci. 82:3549-3559

Linke, P. L., J. M. DeFrain, A. R. Hippen, and P. W. Jordon. 2004. Ruminal and plasma responses in dairy cows to drenching or feeding glycerol. J. Dairy Sci. 87(Suppl. 1):343. (Abstr.)

Mach, N., A. Bach, and M. Devant. 2009. Effects of crude glycerin supplementation on performance and meat quality of Holstein bulls fed high-concentrate diets. J. Anim. Sci. 87:632-638.
McGowan, M. W., J. D. Artiss, D. R. Strandbergh, and B. A. Zak. 1983. A peroxidase-coupled method for the colorimetric determination of serum triglycerides. Clin. Chem. 29:538-542.

Neel, J. P., E. C. Prigge, and E. C. Townsend. 1995. Influence of moisture content of forage on ruminal functional specific gravity and passage of digesta. J. Anim. Sci. 73:3094-3102.

NRC. 2001. Nutrient Requirements of Dairy Cattle. 7th rev. ed. Natl. Acad. Sci., Washington, DC.

Osborne, V. R., N. E. Odongo, J. P. Cant, K. C. Swanson, and B. W. McBride. 2009. Effects of supplementing glycerol and soybean oil in drinking water on feed and water intake, energy balance, and production performance of periparturient dairy cows. J. Dairy Sci. 92:698-707.

Overton, T. R., and M. R. Waldron. 2004. Nutritional management of transition dairy cows: Strategies to optimize metabolic health. J. Dairy Sci. 87(Suppl.):E105-E119.

Plaizier, J. C., A. Martin, T. Duffield, R. Bagg, P. Dick, and B. W. McBride. 2000. Effect of a prepartum administration of monensin in a controlled-release capsule on apparent digestibilities and nitrogen utilization in transition dairy cows. J. Dairy Sci. 83:29182925

Rémond, B., E. Souday, and J. P. Jouany. 1993. In vitro and in vivo fermentation of glycerol by rumen microbes. Anim. Feed Sci. Technol. 41:121-132.

SAS Institute. 1999. SAS/STAT User's Guide: Statistics, Version 9.2 Edition. SAS Institute Inc., Cary, NC.

Sehested, J., L. Diernaes, P. D. Møller, and E. Skadhauge. 1999. Ruminal transport and metabolism of short-chain fatty acids (SCFA) in vitro: Effect of SCFA chain length and $\mathrm{pH}$. Comp. Biochem. Physiol. A Mol. Integr. Physiol. 123:359-368.

Sellers, R. S. 2008. Glycerin as a feed ingredient, official definition(s) and approvals. J. Dairy Sci. 91(E-Suppl. 1):392. (Abstr.)

St-Pierre, N. R., and D. Glamocic. 2000. Estimating unit costs of nutrients from market prices of feedstuffs. J. Dairy Sci. 83:14021411.

Thompson, J. C., and B. B. He. 2006. Characterization of crude glycerol from biodiesel production from multiple feedstocks. Appl. Eng. Agric. 22:261-265.

Trinder, P. 1969. Determination of blood glucose using an oxidase peroxidase system with a non-carcinogenic chromogen. J. Clin. Pathol. 22:158-161.

Wildman, E. E., G. M. Jones, P. E. Wagner, R. L. Boman, H. F. Troutt Jr., and T. N. Lesch. 1982. A dairy cow body condition scoring system and its relationship to selected production characteristics. J. Dairy Sci. 65:495-501.

Williamson, D. H., J. Mellanby, and H. A. Krebs. 1962. Enzymic determination of $\mathrm{d}(-)-\beta$-hydroxybutyric acid and acetoacetic acid in blood. Biochem. J. 82:90-96.

Woodford, S. T., M. R. Murphy, and C. L. David. 1984. Water dynamics of dairy cattle as affected by initiation of lactation and feed intake. J. Dairy Sci. 67:2336-2343. 